\title{
Analysis Of Fertile Age Couples Interest Using Iud As A Contraception Method Based On Factors Affecting In Sugihwaras Public Health Center
} Puji lestari, Beyba melda suhita,
Katmini

Master Program in Public Health, Institute of Health Sciences Strada Indonesia, Kediri

Email:

pujilestariindra75@gmail.com

Received : October 5, 2020

Accepted : November 27, 2020

Published : November 30, 2020
CCA interest in using an IUD as an IUD (Contraception Tool in the Womb) in the work area of the Sugihwaras Community Health Center is still low. This is caused by several factors. The purpose of this research is to find out the most dominant factor influencing CCA interest in using an IUD as a contraceptive device in the work area of the Puskesmas Sugihwaras Bojonegoro. The design of this study used an observational method with a cross sectional approach. With a population of all couples of childbearing age who use the IUD as a contraceptive in the work area of the Sugihwaras Health Center, which is 175 people. By using purposive sampling technique obtained a sample size of 122 respondents. The independent variables in this study were acceptor confidence, service quality, environmental culture, and family support. While the dependent variable is CCA interest in using an IUD as a contraceptive. The results showed that the $\mathrm{p}$ value for the acceptor confidence variable was $0.017<0.05$ so that the acceptor confidence variable had an influence on the acceptor's interest. $P$ value of service quality $0,000<0.05$ so that service quality variables have an influence on the acceptor's interest. $\mathrm{P}$ value of environmental culture $0.035<0.05$ so that environmental culture has an influence on the acceptor's interest. P value of family support $0.001<0.05$ so that family support has an influence on the acceptor's interest. Of all the independent variables that have the strongest signification value is service quality. So the hypothesis is accepted. That means that service quality is the factor that has the most influence on CCA interest in using an IUD as a contraceptive in the work area of the Sugihwaras Community Health Center.

Keywords: IUD, Contraception, Factors

Copyright @ 2020 IIK STRADA Indonesia All right reserved.

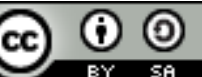

This is an open-acces article distributed under the terms of the Creative Commons Attribution-ShareAlike 4.0 International License.

\section{INTRODUCTION}

Population growth in the world has increased from time to time, especially in developing countries like Indonesia. To control the population, the Government of the Republic of Indonesia has launched the Family Planning Program (KB). According to Law No. 52 of 2009 concerning Population Development and Family Welfare Development, which is an effort to regulate child birth, distance and age for childbirth, regulate pregnancy by means of promotion, protection, and assistance in accordance with reproductive rights to create quality and prosperous families. (Republic of Indonesia Constitution, 2009).

In fact many difficulties experienced by women in determining the appropriate contraception for him. Constraints that are often found arise due to lack of knowledge. Many aspects must be considered in the choice of contraception which includes the degree of health 
status, the possibility of side effects, the possibility of failure or unwanted pregnancy, the number of expected family ranges, the consent of the husband or wife, cultural values, environment and family and so forth (Affandi, 2011). The choice of contraceptive method can be influenced by several factors, namely the quality of service, belief in the CCA of family planning acceptors, environmental culture, and family support. This is consistent with research conducted by Gertler and Molyneaux (2003) where more than 50\% of family planning users have good knowledge and are not much different from research conducted by Sindhung (1999), as many as 60\% of mothers have good knowledge about family planning ( Syafitri, 2010).

Thus, knowledge is very influential on the successful use of contraception and the family planning program will run well too. Based on the results of an initial survey of research data at the Sugihwaras Health Center there were 7298 active family planning participants, but the use of IUDs and IUDs was still relatively low, respectively around $20.2 \%$ and $24 \%$. Based on the description above, the writer would like to research on "Analysis of CCA interest in using an IUD as a Contraception Tool based on Factors that influence in Sugihwaras Health Center".

\section{METHODS}

The research design is a structured work plan in terms of relationships between variables in a comprehensive manner, so that the results of the research can provide answers or research questions. The plan includes the things that researchers do starting from making hypotheses and their operational implications to the final analysis (Husein, 2013). In this study, the research design used was an observational research design with a cross sectional approach. The cross sectional approach is a research design that studies the dynamics of the correlation between risk factors and effects, by approaching, observing or collecting data at one time / once (Notoadmodjo, 2010). In this study, researchers aimed to find out the dominant factors affecting the CCA of the IUD method in the work area of the Sugihwaras Health Center, Bojonegoro Regency. The research will be conducted at the Sugihwaras Health Center, Sugihwaras District, Bojonegoro Regency. The research will be conducted in January 2020 until February 2020.

\section{RESULTS}

\section{Description of Place of Study}

The Sugihwaras Community Health Center is located on Jalan Raya Sugihwaras No.845, Sugihwaras District, Bojonegoro Regency. Based on observations of the visible condition of the activity the location of the Sugihwaras Public Health Center is bordered as follows:

- North side: Balen District and Kapas District

- East side: Kedungadem District

- To the south: Temayang District

- West side: Temayang District and Kapas District

The working area of the Sugihwaras Health Center is $87.15 \mathrm{~km} 2$, consisting of $75 \%$ of the lowlands and $25 \%$ of the highlands.

\section{Descriptive Public Data}

Table 1. Binary Logistic Regression Test Results Confidence in Acceptance of Interest.

\begin{tabular}{lllll}
\hline \multicolumn{5}{l}{ Binary Logistic Regression Acceptor Confidence in Interest } \\
\hline Step 1 & \multicolumn{1}{c}{ Chi-square } & df & Sig. \\
& Step & 6,129 & 1 & 0,013 \\
& Block & 6,129 & 1 & 0,013 \\
& Model & 6,129 & 1 & 0,013 \\
\hline
\end{tabular}

From the binary logistic regression test between acceptor's belief in interests, it can be seen that the $\mathrm{p}$ value is $0.013<0.25$, so the acceptor's confidence variable qualifies as a candidate in the multivariate regression test

binary logistics.

Table 2. Binary Logistic Regression Test Results for Service Quality on Interest. Logistic Regression of Service Quality Against Interest

\begin{tabular}{|c|c|c|c|c|}
\hline \multicolumn{5}{|c|}{ Logistic Regression of Service Quality Against Interest } \\
\hline Sten 1 & Step & $\begin{array}{l}\text { Chi-square } \\
10,746\end{array}$ & df & Sig. \\
\hline
\end{tabular}




$\begin{array}{llll}\text { Block } & 10,746 & 1 & 0,001 \\ \text { Model } & 10,746 & 1 & 0,001\end{array}$

From the binary logistic regression test between service quality and interest, it can be seen that the $\mathrm{p}$ value is $0.001<0.25$, so the service quality variable qualifies as a candidate in the multivariate binary logistic regression test.

Table 3. Binary Logistic Regression Test Results of Environmental Culture on Interests. Logistic Regression of Environmental Culture on Interests

\begin{tabular}{|c|c|c|c|c|}
\hline & & Chi-square & $\mathrm{df}$ & Sig. \\
\hline \multirow[t]{3}{*}{$\overline{\text { Step } 1}$} & Step & 10,336 & 1 & 0,001 \\
\hline & Block & 10,336 & 1 & 0,001 \\
\hline & Model & 10,336 & 1 & 0,001 \\
\hline
\end{tabular}

From the binary logistic regression test between environmental culture to interests, it can be seen that the $\mathrm{p}$ value is $0.001<0.25$, so that the environmental culture variable qualifies as a candidate in the binary logistic regression multivariate test.

Table 4. Binary Logistic Regression Test Results for Family Support for Interest.

\begin{tabular}{|c|c|c|c|c|}
\hline \multicolumn{5}{|c|}{ Logistic Regression of Environmental Culture on Interests } \\
\hline & & Chi-square & df & Sig. \\
\hline \multirow[t]{3}{*}{ Step 1} & Step & 10,327 & 1 & 0,016 \\
\hline & Block & 10,327 & 1 & 0,016 \\
\hline & Model & 10,327 & 1 & 0,016 \\
\hline
\end{tabular}

From the binary logistic regression test between family support for interest, it can be seen that the $\mathrm{p}$ value is $0.016<0.25$, so the family support variable qualifies as a candidate in the multivariate regression test

binary logistics.

Table 5. Multivariate Test Results of Independent Variables Against Dependent Variables with Binary Logistic Regression.

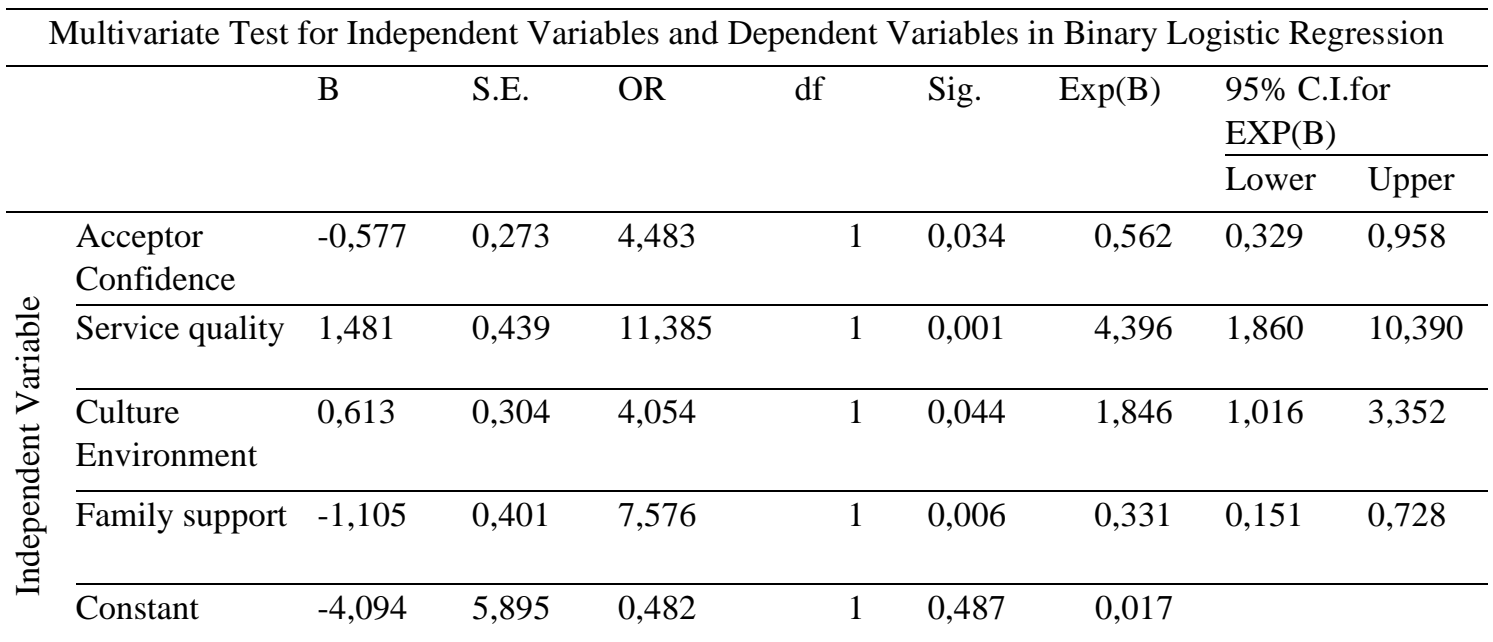

Judging from the table of multivariate test results above to see the partial effect of the independent and dependent variables it can be concluded that;

1. The Acceptor Confidence Variable (X1) has a p-value of $0.034<0.05$ which influences the Interest in Using the IUD (Y)

2. Service Quality Variable (X2) has a p-value of $0.001<0.05$ affecting the Interest in Using the IUD (Y)

3. Environmental Cultural Variable (X3) has a p-value of $0.044<0.05$ which influences the Interest in Using the IUD (Y) 
4. Family Support Variable (X4) has a p-value of $0.006<0.05$ which influences the Interest in Using the IUD (Y)

From the table above, it is known that the highest OR value is owned by the Service Quality variable. Therefore, the most influential variable on CCA interest in using an IUD is the service variable. All variables have a p-value $<0.05$, so all independent variables (acceptor confidence, service quality, environmental culture and family support) have an influence but are not significant to the interest of CCA in using an IUD as a contraceptive device. From the results obtained from the aforementioned statistical tests, it can be seen that $\mathrm{H} 0$ which said that the most dominant factor towards the CCA interest in using an IUD in the Sugihwaras Puskesmas work area was acceptable.

\section{DISCUSSION}

From the data in table 4.28 (cross tabulation between quality and interest in CCA), it is known that respondents who responded to good service quality and were interested in using an IUD were 52 respondents $(43 \%)$ out of a total of 122 respondents. This shows that the quality of service affects the CCA interest in using an IUD and is strengthened by the univariate test, the p-value of the service quality is $0.001<0.25$. According to Husein (2007) customer satisfaction is determined by customer perceptions of product or service performance in meeting customer expectations. Customers are satisfied when customer expectations are exceeded. Supported by the results of the study entitled Imbarwati (2010) The use of contraceptive devices for IUDs in non-IUD family planning participants in the Pedurungan sub-district of Semarang", one of the factors influencing interest in using an IUD by acceptors is the quality of service. It can be argued that, if the quality of IUD services has an indication of lack, the CCA will also be reluctant in using an IUD, because with the quality of service it is expected that CCAs will also get 92 of their wishes to use the IUD fulfilled. Therefore, there is a correlation between historical data and the results obtained.

The influence of acceptor beliefs on CCA interest is shown in table 4.29 (cross tabulation between acceptor beliefs and CCA interest). From the table it is known that respondents who are interested in using an IUD and answer that they believe in an IUD are 66 respondents (54\%) out of a total of 122 respondents. The univariate test results obtained the $\mathrm{p}$ value of the acceptor's confidence is $0.013<0.25$, which indicates that the acceptor's beliefs have an influence on the interest of CCA using an IUD as a contraceptive. According to Frisca Liando, in a study entitled "Factors Associated with the Use of Contraception in the Womb", the belief in a receptor can be formed through an effort in promoting promotion in the use of an IUD. Because the acceptor's belief is one of the supporting factors in the use of the IUD. The acceptor's belief is the most determining factor in CCA's interest in using an IUD as a contraceptive device. From faith will form an attitude of trust and take action to tend to do what is believed by CCA. The acceptor's beliefs have a close relationship with the culture of the surrounding environment. Because the conditions around CCA are known every day, it will indirectly instill a belief and a stigma within CCA itself. Included in the use of an IUD, if CCA has confidence in the IUD, then the acceptor's interest is also higher using an IUD as a contraceptive.

The influence of environmental culture on CCA interest in using an IUD as a contraceptive is shown in table 4.30 (cross tabulation between environmental culture and interest). In the table it is known that CCAs who are interested in using an IUD as a contraceptive device and answer that environmental culture is one of the influencing factors is 67 respondents $(54 \%)$ out of a total of 122 respondents. Univariate test results obtained p value from the acceptor's belief is $0.001<0.25$, which indicates that environmental culture has an influence on the interest of CCA using IUD as a contraceptive. According to the research conducted by Iis Rahayu entitled "Relationship between Ibu CCA and the use of an IUD in Nagari Andalas Baruh Bukit, Sungayang District, Tanah Datar District", environmental traditions or culture are factors that influence the selection of an IUD as a contraceptive device. This indicates that the environment has a stigma that the IUD is a reliable contraceptive method for accuracy, and the public's view of the IUD method is also quite high. This correlates with the role of midwives as motivators and educators for CCA in choosing contraception.

It can be said that if environmental culture is influential, the influence is obtained from the role of midwives as educators in family planning. If the level of CCA that is interested in using an IUD and assumes that environmental culture is influential, means the role of the midwife in shaping 
the environmental culture in using the IUD method can be said to be a factor influencing CCA interest in choosing an IUD

as a contraceptive.

The influence of family support on CCA interest in using an IUD in the work area of the Sugihwaras Community Health Center can be seen from table 4.31 (cross tabulation between family support and CCA interest). From the table it is known that CCAs who are interested in using an IUD and answer that their family supports are 54 respondents (44\%) of the total 122 respondents. The univariate test results obtained the $\mathrm{p}$ value of the acceptor's confidence is $0.016<0.25$ which indicates that the acceptor's beliefs have an influence on the interest of CCA using an IUD as a contraceptive. According to Dwi Puspitasari in a study entitled "Family Support in Family Planning Participation in Fertile Age Couples in Argomulyo Sedayu Village Bantul Yogyakarta", that the low number of IUD users in Argomulyo Village, one of which was influenced by the low family support in participating in the KB program, so that family support was also become one of the factors that influence interest in using contraception. Based on the results of research family support has an influence on the interest in CCA using an IUD. There is a correlation between beliefs and environmental culture, in the implementation found in the field, if the environmental culture has been formed through counseling conducted by midwives or cadres related to the IUD, causing the stigma and knowledge of the community to increase the IUD. Does not rule out the possibility that when counseling is done, the family from CCA also accompanied. Such conditions can form a positive stigma on the part of the family and generat a support from the family and from the support of the family it also forms the CCA belief in using the IUD itself.

From the multivariate test results between the dependent and independent variables using binary logistic regression it is known that the variable of acceptor confidence, service quality, environmental culture, and family support simultaneously influence the interest of CCA in using the IUD. It is known from the $\mathrm{p}$ value of each variable has a value $<0.05$ and can be interpreted simultaneously the four independent variables affect the dependent variable (CCA interest in using an IUD). From the description above, it can be seen that the most influential factor on CCA interest in using an IUD is the service quality factor where the service quality variable in the multivariate test has the highest OR, ie. 11,385. Strengthened from the results of Imbarwati's research that examined the use of IUD contraceptives for non-IUD family planning acceptors in Semarang, which concluded that the interest in family planning acceptors in using an IUD was influenced by the quality of health services.

Broadly speaking, of the four factors that influence the interest of CCA in using using an IUD can be divided into two, namely the factor of CCA and the factor of health workers. Factors originating from CCA include: Acceptor beliefs, environmental culture and family support. These three factors have a pretty close correlation. In the counseling phase, it is possible for the family of CCA to assist and even counseling related to IUD is done in the family environment of CCA. The impact of this is that the family is promoted to support CCA in using the IUD. So that it forms a factor of family support for CCA users of the IUD. From the two aspects above, environmental culture and family support will add to the belief of CCA itself in using the IUD as a contraceptive. This will form the acceptor belief factor side. If the CCA itself feels confident in using the IUD, then the determining factor is the quality of service. If the quality of getting an IUD service is easy and good, it is certain that the CCA will also choose the IUD as a contraceptive device.

However, if on the contrary, it is possible that CCA will switch to other methods of contraception that are considered easier and better in terms of service quality. From the explanation of the effect of each variable on CCA interest in using an IUD as a contraceptive, all of these variables have an influence with different levels of significance. However, all variables will affect and form other variables. So that it can simultaneously be said that the variables of service quality, acceptor beliefs, environmental culture and family support shape CCA's interest in using an IUD as a contraceptive device.

\section{CONCLUSION}

Service quality is a factor influencing CCA interest in using IUD in the work area of the Puskesmas Sugihwaras, Bojonegoro with a significance level of 0.001 and most CCA interested in using an IUD get good service. The acceptor's belief is a factor influencing CCA interest in using an IUD in the work area of the Puskesmas Sugihwaras, Bojonegoro with a significance level of 0.034 and 
most CCA interested in using an IUD are confident about the IUD itself. Environmental culture is a factor that influences CCA interest in using IUD in the work area of Puskesmas Sugihwaras, Bojonegoro with a significance level of 0.044 and most CCAs interested in using an IUD are influenced by the culture of the neighborhood. Family support is a factor influencing CCA interest in using an IUD in the work area of the Puskesmas Sugihwaras, Bojonegoro with a significance level of 0.006 and. most CCAs are interested in using an IUD

get support from families in choosing an IUD as a contraceptive. Quality of service is the most influential factor on CCA interest in using IUD as a contraceptive device in the work area of the Sugihwaras Community Health Center, Bojonegoro Regency with an OR value of 11,385.

\section{ACKNOWLEDGMENTS}

The author is thankful for respondents for their valuable information and its awareness to participate in this research.

\section{CONFLICTS OF INTEREST}

The author declares that they have no conflict of interest

\section{REFERENCES}

Affandi, B, dkk. (2011). Buku Panduan Praktis Pelayana Kontrasepsi. Jakarta : Bina Pustaka Sarwono Prawiroharjo.

Aziz, A. (2013). Metode Penelitian Kebidanan Teknik Analisis Data, Jakarta : Salemba Medika.

BKKBN. (2010). Buku Panduan Praktis Pelayanan Kontrasepsi. Jakarta : PT.Bina Pustaka Sarwono Prawiroharjo.

BKKBN. (2012). Buku Pedoman Pengelolaan Bina Keluarga Remaja (BKR). Jakarta : BKKBN. BPS.

BKKBN. (2013). Pemantauan Pasangan Usia Subur Melalui Mini Survei. Jakarta : BPS.

BKKBN. (2014). Buku Panduan Praktis Pelayanan Kontrasepsi Edisi 3. Jakarta : PT.Bina Pustaka.

BKKBN. (2015). Survei Demografi Kesehatan Indonesia 2015. Jakarta : BPS.

BKKBN. (2016). Pembangunan Kependudukan Jawa Timur. Jakarta : BPS.

Depkes, RI. (2011). Target Tujuan Pembinaan MDGs. Direktorat. Jendral. Jakarta : Kesehatan Ibu dan Anak

Handayani. (2010). Buku Ajar Pelayanan KB. Yogyakarta : Pustaka Rihana.

Hidayat, A, A. (2014). Metode Penelitian Kebidanan dan Teknin Analisis Data. Jakarta : Salemba Medika.

Husein U. (2013). Metode Penelitian untuk Skripsi dan Tesis. Jakarta : Rajawali.

ILUNI. FKUI. (2010). Keluarga Berencana.

Imbarawati. (2009). Beberapa Faktor yang Berkaitan dengan Penggunaan KB IUD pada Peserta KB Non IUD di Kecamatan Pendurungan Kota Semarang. Jurnal Kesmas. 31-32.

Kemenkes, RI. (2016). Profil Kesehatan 2016. Jakarta : Kemenkes RI. 